\title{
Brazilian Maize Landraces Silks as Source of Lutein: An Important Carotenoid in the Prevention of Age-Related Macular Degeneration
}

\author{
Shirley Kuhnen ${ }^{1 *}$, Paulo Fernando Dias ${ }^{2}$, Juliana Bernardi Ogliari ${ }^{3}$, Marcelo Maraschin ${ }^{4}$ \\ ${ }^{1}$ Biochemistry and Animal Morphophysiology Laboratory, Departament of Zootechny and Rural Development, CCA, Federal \\ University of Santa Catarina (UFSC), Florianopolis, Brazil; ${ }^{2}$ Laboratory of Studies in Bioactivity and Animal Morphogenesis \\ Departament of Cell Biology, Embriology and Genetics, CCB, Federal University of Santa Catarina (UFSC), Florianopolis, Brazil; \\ ${ }^{3}$ Studying Group in Agricultural Biodiversity, Departament of Phytotechny, CCA, Federal University of Santa Catarina (UFSC), \\ Florianopolis, Brazil; ${ }^{4}$ Plant Morphogenesis and Biochemistry Laboratory, CCA, Federal University of Santa Catarina (UFSC), \\ Florianopolis, Brazil. \\ Email: *shirley@cca.ufsc.br
}

Received August $28^{\text {th }}, 2012$; revised September $28^{\text {th }}, 2012$; accepted October $5^{\text {th }}, 2012$

\begin{abstract}
The carotenoid composition of the silk tissue of Zea mays (L.) has not been investigated despite its large occurrence in maize grains. For the purpose of evaluating maize silk as a source of carotenoids, samples from eight landraces developed and cultivated in Southern Brazil were assayed. The silk samples were harvested from individual plants through the fourth and seventh day after they emerged, frozen in liquid $\mathrm{N}_{2}$, and lyophilized. The carotenoids were extracted with a $\mathrm{MeOH} /$ toluene solution $(1: 1, \mathrm{v} / \mathrm{v}), 30 \mathrm{~min}$, and saponified $\left(15 \% \mathrm{KOH}, 12 \mathrm{~h}, 40^{\circ} \mathrm{C}\right)$. The RP-HPLC-UVvisible analysis revealed lutein as the main carotenoid $(88.75 \%)$ in maize silks, with a wide range of contents (dry weight), i.e. $39.11 \mu \mathrm{g} \cdot \mathrm{g}^{-1}$ (Palha Roxa 18) to $176.12 \mu \mathrm{g} \cdot \mathrm{g}^{-1}$ (Língua de Papagaio) among the studied genotypes. Smaller amounts of trans- $\beta$-carotene, $\alpha$-carotene, and zeaxanthin were also detected. The results revealed that in parallel to the claimed high genetic variability of maize landraces, a quite variable carotenoidic composition of silk tissue seems to occur in the germoplasm cultivated in Southern Brazil. Taking into account the usage of lutein for the prevention of several pathologies, especially the age related macular degeneration, some maize landraces (e.g. Língua de Papagaio and Rosado) might be interesting sources of a lutein-rich extract that could add value to an underutilized biomass.
\end{abstract}

Keywords: Lutein; Maize Landraces; Silks

\section{Introduction}

The carotenoids are pigments that have been widely distributed in nature and that are responsible for the coloring of several foods, varying from yellow to red. Those secondary metabolites are divided into two main groups: carotenes that have in their structures only carbon and hydrogen atoms and the xanthophylls (oxicarotenoids), which contain oxygenated functional groups, such as hydroxyls, ketones, and epoxides. It is estimated that about 50 carotenoids might be important to human nutrition and that at least 40 of them act as precursors in the synthesis of retinoid compounds, the bioactive forms of vitamin A [1], with the exception of the xanthophylls lutein and zeaxanthin. However, there is increasing interest in these xanthophylls, since several benefits to human

"Corresponding author. health have been attributed to them, e.g. antioxidant, protective activities against UV radiation, anti-angiogenic, reduction of the risk of atherosclerosis, anti-carcinogenic, and especially age-related macular degeneration (AMD) [2-7]. In fact, lutein is know to many as "the eye-protective nutriente" [8]. Evidence suggests that lutein consumption in inversely related to AMD and other eye diseases. This is supported by the finding that lutein and zeaxanthin are deposited in the lens and the macula lutea, an area of the retina responsible for central and high acuity vision [9]. These protective effects of xanthophylls have been related to their properties of oxygen free radical scavengers and also act as a filter of high energy blue light [10].

Only plants are capable of synthesizing carotenoids being, therefore, the unique source of those nutrients to animals that incorporate them through feeding [11]. Among the main food sources of lutein and zeaxanthin 
are cabbage, broccoli, lettuce, parsley, peas, spinach, watercress, and maize. Although the major carotenoids of maize grains are zeaxanthin and lutein [12,13], few studies have been performed exploring other tissues/ organs (e.g. silk tissue) as potential sources of those secondary metabolites.

The largest part of the world's production for manufactured products based on lutein comes from Tagetes erecta L. (marigold flowers), a species with low biomass yield (e.g. $\sim 240 \mathrm{~kg} \cdot \mathrm{ha}^{-1}$ ) [14]. This fact cooperates decisively for the high market price of lutein-containing marketed products. This way, the continuous searching for new sources of lutein/zeaxanthin aims at supplying the demand of the carotenoid market worldwide, which has been expanding [15].

The advantage of using maize as a source of carotenoids is due to the great importance of this cereal worldwide and in Brazil, the third largest producer of maize worldwide -52.7 million tons - 2010/2011 harvest [16]. Maize is a major source of food for both humans and animals. The United States, China, and Brazil produced 547.3 million metric tons of that cereal in 2010 [17]. Maize has been grown mostly for the grain production and the other parts of the plant are under-exploited by farmers (e.g. silage from leaves and stalks for feeding cattle) and industry. The current study is part of an ongoing project that has been carried out in southern Brazil in association with small farmers that have developed and cultivated $c a .32$ maize landraces [18]. The main goal of such a project is to gain more insights regarding the germoplasm as a source of bioactive compounds, and as an added-value strategy to maizederived products of interest to small farmers. Thus, this study aims to investigate the potential of stigma/style (maize silk) as a source of carotenoids considering the well known occurrence of those pigments in maize grains. To the authors' best knowledge this is the first report on the occurrence of lutein in the silk tissue of Zea mays, which is a carotenoid with elevated value in the international market.

\section{Materials and Methods}

\subsection{Maize Varieties}

The seeds of eight maize landraces originated from Anchieta county, Santa Catarina State, southern Brazil (latitude $26^{\circ} 30^{\prime} \mathrm{S}$ and longitude $50^{\circ} 30^{\prime} \mathrm{W}$ ) (Figure 1) were donated by a local small farmer association (SINTRAF/SC) to the Federal University of Santa Catarina in accordance with the current Brazilian legislation on

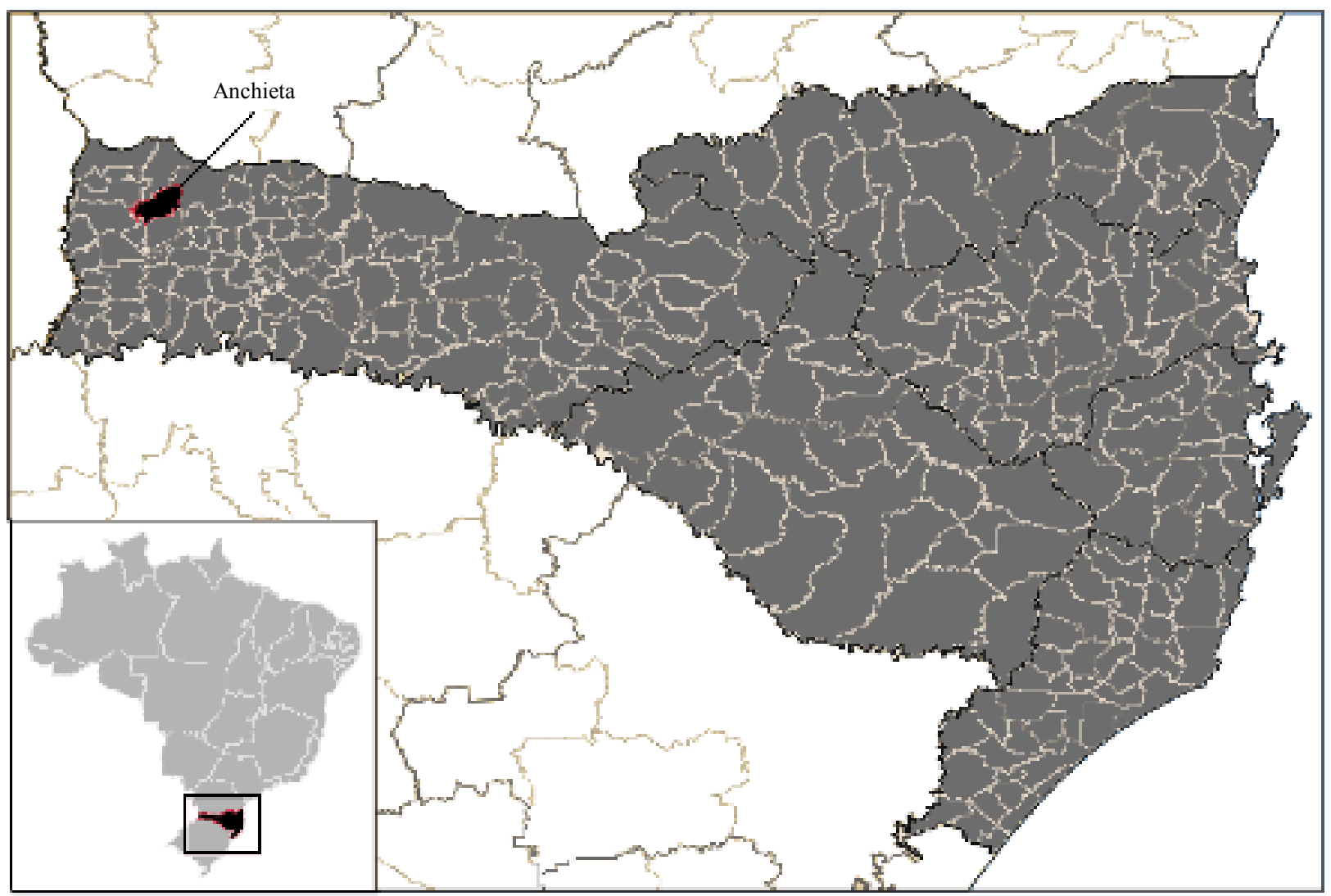

Figure 1. Geopolitical map of Santa Catarina State in Brazil demonstrating the location of the Anchieta county. 
biodiversity usage and assay (Genetic Heritage Management Council-Provisional Act 2.186-16, August 23, 2001). Table 1 shows the principal agronomic characteristics of those genotypes, such as grain type, grain color, plant height, cycle duration, and productivity, as previously reported [19]. According to their local names, the maize landraces were encoded as Língua de Papagaio, Roxo 29, Roxo 41, Mato Grosso Palha Roxa, Rosado, Rajado 8 Carreiras, Cateto Vermelho, and Palha Roxa. The maize landrace populations were agro-ecologically cultured (Florianópolis, Santa Catarina State, Southern Brazil, September 2005), at a population density of 20,000 plants $\mathrm{ha}^{-1}$. The silk samples $(0.5-5.0 \mathrm{~g}$, fresh weight) were harvested through the fourth and seventh days after they emerged from the husk, from individual plants, and immediately frozen in liquid $\mathrm{N}_{2}$. Furthermore, the samples were lyophilized and stored at $-18^{\circ} \mathrm{C}$ until further analysis. All the chemicals used were purchased from Vetec and Tedia Brazil (Rio de Janeiro, Brazil) and were of reagent or HPLC grade.

\subsection{Extraction Procedure}

The lyophilized maize silks ( $1 \mathrm{~g}$ /individual; $\mathrm{n}=8$ individuals/variety) was reduced to a fine powder with liquid $\mathrm{N}_{2}$ and extracted with $12 \mathrm{~mL}$ of $\mathrm{MeOH} /$ toluene solution $(1: 1, \mathrm{v} / \mathrm{v})$, for 30 minutes, at room temperature. The extracts were vacuum-filtered through a sintered glass funnel on a cellulose membrane $(0.45 \mu \mathrm{m})$ to remove particles. The organosolvent extract was evaporated under $\mathrm{N}_{2}$ flux and dissolved in isopropanol $(1: 1.5, \mathrm{w} / \mathrm{v})$ and $15 \% \mathrm{KOH}(5: 3, \mathrm{v} / \mathrm{v})$, for 12 hours, at $40^{\circ} \mathrm{C}$, for the purpose of saponification. The mixture was then diluted with water $(1: 3, \mathrm{v} / \mathrm{v})$ and partitioned against ethyl acetate three times. The combined ethyl acetate was dried over anhydrous sodium sulfate and evaporated to dryness in vacuum. This dried saponification product was redissolved in hexane and analyzed by RP-HPLC-UV-vis. All the experiments were performed in triplicate. Due to the susceptibility of carotenoids to isomerization, precautionary measures to prevent artifact formation and losses during the handling and extraction process were taken. The procedures were rigorously followed: 1) completion of the analysis within the shortest possible time; 2) replacement of the vial's internal atmosphere by $\mathrm{N}_{2} ; 3$ ) protection from light, and 4) avoiding contact with acid and heat.

\subsection{RP-HPLC-UV-Vis}

A concentrated sample $(10 \mu \mathrm{L}$, with triplicate analysis $)$ was injected into a liquid chromatograph (Shimadzu LC-10A; Shimadzu, Kyoto, Japan) equipped with a C18 reverse-phase column (Vydac 218TP54; $250 \mathrm{~mm} \times 4.6$ $\mathrm{mm} \varnothing, 5 \mu \mathrm{m}, 30^{\circ} \mathrm{C}$ ), protected by a $5 \mu \mathrm{m} \mathrm{C} 18$ reversephase guard column (Vydac 218GK54). The eluent was MeOH: $\mathrm{CH}_{3} \mathrm{CN}\left(80: 20, \mathrm{v} / \mathrm{v}, 1 \mathrm{~mL} \cdot \mathrm{min}^{-1}\right)$ and the detection of carotenoids was performed by reading the absorbance at $450 \mathrm{~nm}$. The identification of the compounds of interest was performed using the retention times of standard compounds obtained under the same experimental conditions (Sigma-Aldrich, St. Louis, MO, USA). The quantification of the carotenoids used external standard curves $\left[0.5 \mu \mathrm{g} \cdot \mathrm{mL}^{-1}\right.$ to $45 \mu \mathrm{g} \cdot \mathrm{mL}^{-1}$ for both lutein and zeaxanthin $\left(\mathrm{r}^{2}=0.99\right)$, and $0.01 \mu \mathrm{g} \cdot \mathrm{mL}^{-1}$ to $12 \mu \mathrm{g} \cdot \mathrm{mL}^{-1}$ for $\beta$-carotene $\left.\left(\mathrm{r}^{2}=0.98\right)\right]$ obtained under the same experimental conditions.

\section{Results and Discussion}

The majoritarian carotenoid identified by RP-HPLC-UVvis in the oleoresin extracted from the silk lyophilized samples was lutein ( $\beta, \varepsilon$-carotene-3, 3-diol). Apart from that, small quantities of pro-vitamin A carotenoids, $\alpha$-carotene $(\beta, \varepsilon$-carotene), trans- $\beta$-carotene $(\beta, \beta$-carotene),

Table 1. Grain color and type, cultivation cycle, plant height, number of cobs per plant, and productivity of the studied maize varieties cultivated in Southern Brazil.

\begin{tabular}{|c|c|c|c|c|c|c|}
\hline Maize landraces & Grain color & Grain type & $\begin{array}{c}\begin{array}{c}\text { Cultivation cycle } \\
\text { (days) }\end{array} \\
\end{array}$ & $\begin{array}{l}\text { Plant height } \\
\text { (m) }\end{array}$ & $\begin{array}{c}\text { Number of cobs } \\
\text { per plant }\end{array}$ & $\begin{array}{l}\text { Productivity of } \\
\text { grains }\left(\mathrm{Kg} \cdot \mathrm{ha}^{-1}\right)\end{array}$ \\
\hline Cateto Vermelho ${ }^{\mathrm{b}}$ & Yellow and red & semi-dent & - & 2.8 & 1.36 & 7348 \\
\hline Língua de Papagaio $^{\mathrm{a}}$ & Yellow and purple & dent & 111 & 3.1 & 1.00 & 4944 \\
\hline Mato Grosso Palha Roxa ${ }^{a}$ & Yellow and purple & semi-dent & 104 & 3.1 & 1.02 & 4828 \\
\hline Palha Roxa $18^{\mathrm{a}}$ & Yellow and purple & dent & - & 2.8 & 1.34 & 6748 \\
\hline Rajado 8 Carreiras ${ }^{\mathrm{b}}$ & variegated & dent and flint & - & 2.7 & 1.25 & 5454 \\
\hline Rosado $38^{\mathrm{a}}$ & variegated & semi-dent & 109 & 3.3 & 0.97 & 5225 \\
\hline Roxo $29^{\mathrm{a}}$ & purple & dent & - & 3.0 & 1.16 & 5823 \\
\hline Roxo $41^{\mathrm{a}}$ & purple & - & - & - & - & - \\
\hline
\end{tabular}

${ }^{\mathrm{a}}$ Trials carried out in 2002/2003; ${ }^{\mathrm{b}}$ Trials carried out in 2003/2004. Adapted from Canci et al., (2004) [16]. 
and the xanthophyll zeaxanthin ( $\beta, \beta$-carotene-3, 3-diol) were found for some genotypes (Figure 2). For identifycation purposes, the retention times of the sample analytes were compared to those of external standards under the same conditions, and the standards were co-chromatographed with the samples in order to confirm their identity. To the best of our knowledge, these results were never reported before, and the few published studies up to now about the composition of the maize silks have not reported the presence of lutein [20]. Moreover, it is important to consider the predominance of lutein in the ob- tained extract. On average, lutein account for $c a .88 .75 \%$ of the total carotenoids in the oleoresin extracts, varying from 84.87 to $94.35 \%$ for Roxo 29 and Palha Roxa 18 landraces, respectively. Similarly, a wide range of trans- $\beta$-carotene and $\alpha$-carotene was also detected for the maize landraces in the study. Interestingly, no zeaxanthin was detected in the silk samples of most of the maize landraces, e.g. Cateto Vermelho, Língua de Papagaio, Mato Grosso Palha Roxa, Palha Roxa 18, Rajado 8 Carreiras and Rosado (Table 2), despite its occurrence in maize grains as previously reported [21]. Although the

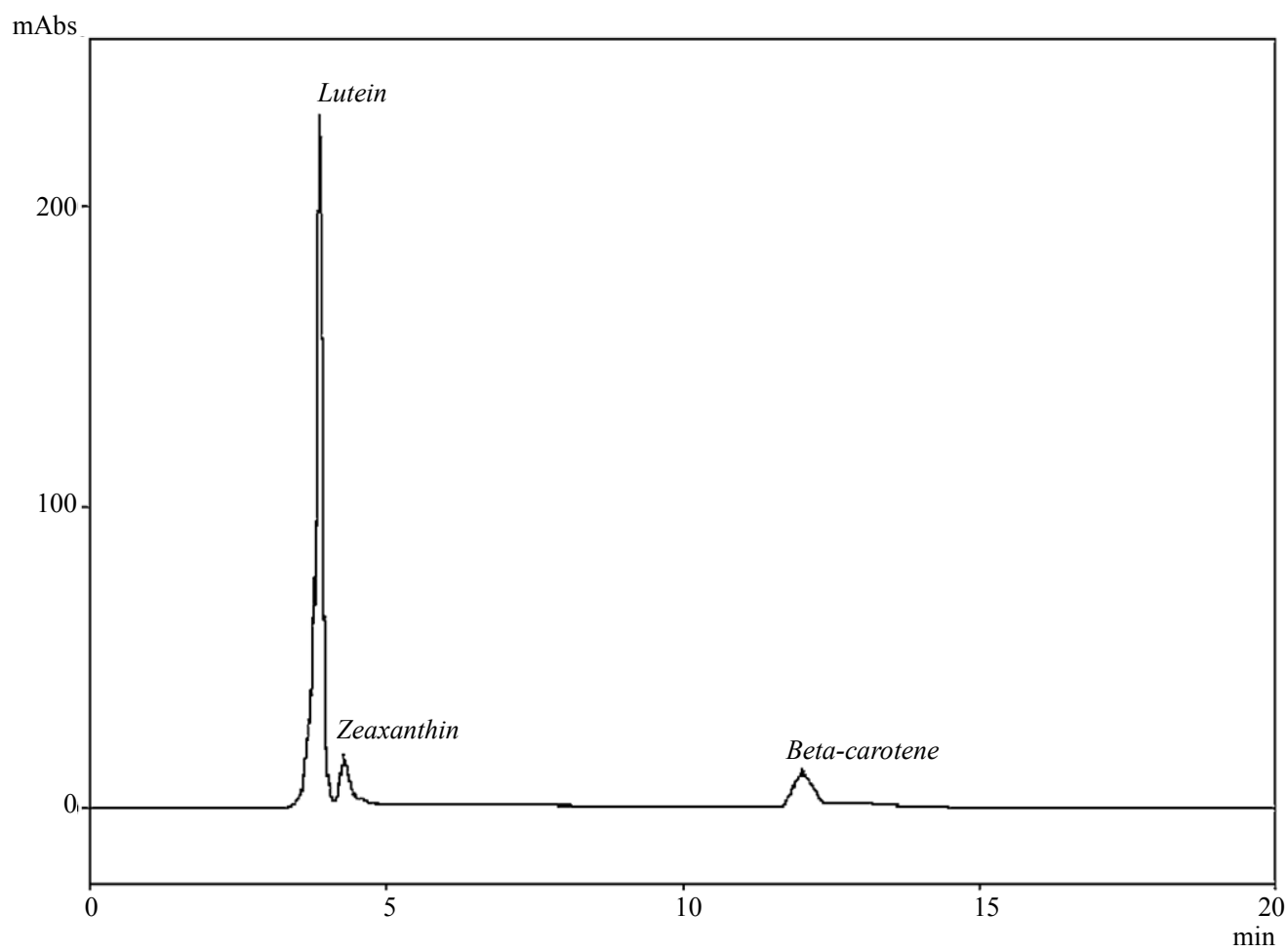

Figure 2. Carotenoid profile of the silk extract of the variety Rajado 8 Carreiras on a Vydac 218TP54 RP column using methanol/ $\mathrm{CH}_{3} \mathrm{CN}(80: 20, \mathrm{v} / \mathrm{v})$ as mobile phase.

Table 2. Xanthophyll and carotene contents $\left(\mu \mathrm{g} \cdot \mathrm{g}^{-1}\right.$, dry weight) determined by RP-HPLC-UV-Vis $(450 \mathrm{~nm})$ of maize landraces silksa (Anchieta county, Santa Catarina State, Southern Brazil).

\begin{tabular}{cccccc}
\hline Varieties & Lutein & Zeaxanthin & trans- $\boldsymbol{\beta}$-carotene & $\boldsymbol{\alpha}$-carotene & Total \\
\hline Cateto Vermelho & $78.52 \pm 6.83$ & n.d. & $7.84 \pm 0.70$ & $1.94 \pm 0.23$ & 88.30 \\
Língua Papagaio & $176.12 \pm 7.55$ & n.d. & $19.93 \pm 1.39$ & $5.84 \pm 0.92$ & 201.89 \\
Mato Grosso Palha Roxa & $95.06 \pm 8.34$ & n.d. & $8.07 \pm 0.74$ & $1.86 \pm 0.05$ & 104.99 \\
Palha Roxa 18 & $39.11 \pm 3.64$ & n.d. & $2.09 \pm 0.30$ & $0.26 \pm 0.22$ & 41.45 \\
Rajado 8 Carreiras & $77.56 \pm 6.66$ & n.d. & $5.97 \pm 0.55$ & $1.57 \pm 0.15$ & 85.10 \\
Rosado & $112.07 \pm 3.73$ & n.d. & $13.16 \pm 1.48$ & $3.93 \pm 0.54$ & 129.16 \\
Roxo 29 & $44.04 \pm 1.96$ & $5.45 \pm 0.33$ & $2.00 \pm 0.09$ & $0.40 \pm 0.35$ & 51.89 \\
Roxo 41 & $51.52 \pm 5.64$ & $0.92 \pm 0.01$ & $5.33 \pm 0.75$ & $1.97 \pm 0.24$ & 59.74 \\
\hline
\end{tabular}

All values are presented as mean \pm SEM of three extractions and three injections $/$ sample; ${ }^{a} n=8$ plants; .d. $=$ not detected. 
carotenoid profile of maize silks has been carried out before pollination, we found that this raw material from inside the maize ear showed a quite similar quali/quantitative carotenoidic composition (data not show).

Maize silks from Língua de Papagaio and Rosado landraces showed the greater potential as sources of lutein due to their higher concentration of the xanthophyll detected (112 and $176 \mu \mathrm{g} \cdot \mathrm{g}^{-1}$, respectively). In contrast, lower amounts of lutein were detected for the biomass samples of Palha Roxa 18 and Roxo 29 landraces (39 and $44 \mu \mathrm{g} \cdot \mathrm{g}^{-1}$, respectively), typically suggesting the existence of any eventual relation between the well known high genetic variability of maize landraces, supporting the highly variable carotenoidic composition found herein, i.e. chemobiodiversity, under homogeneous environmental conditions. Indeed, taking into account that the agronomical traits and the soil and climatic factors were homogeneous over the cultivation cycle of the maize landraces, one might speculate that the intrinsically genetic variability of the studied maize landraces accounted for most of the discrepancies of the carotenoid profiles described herein. In addition, regarding the analysis of anthocyanins and polyphenols, a previous study showed that these varieties are not chemically homogeneous [22]. ${ }^{1}$ H-NMR spectroscopy, followed by principal component analysis (PCA), showed clear discrimination among the maize varieties, pointing out three distinct metabolic profiles. Similarly, the chemical composition of the silks of fifteen maize hybrids with economic importance in Serbia was found to be greatly heterogeneous. The determination of total polyphenols, for example, varied in a wide range between 75.8 and $293.7 \mathrm{mg} \cdot \mathrm{kg}^{-1}$ (dry material) [23]. In fact, for centuries, indigenous communities and small farmers have created thousands of maize varieties taking into consideration the human needs such as grain color, productivity, duration of cycle and others, adapted to fit extremely different environments. Thus, the selection procedures of maize genotypes adopted for several ethnic groups worldwide were correlated, for instance, to their needs for subsistence and according to the environmental conditions. This way, not surprisingly the genetic variability found in maize landraces is appreciable, a trait that seems to be well correlated to the chemical diversity found in several types of biomass from the above mentioned cereal [22-24]. Indeed, in a previous work, our research group detected a wide range $\left(0.12\right.$ to $\left.11.64 \mu \mathrm{g} \cdot \mathrm{g}^{-1}\right)$ of carotenoid contents in 26 landrace maize flour types from Anchieta County [21].

This research contributes to gain insights into the maize landraces cultivated and developed by small farmers in Southern Brazil as sources of bioactive compounds. However, the results found in the present paper suggest that the carotenoid contents of grains are not connected with those in silk tissues. While silks from some landraces, e.g. Roxo 29 and Roxo 41, have lower potential as a source of lutein, their grains have shown the highest content of carotenoids [21]. Thus, the usage of grain coloration as a parameter for the selection of varieties with high potential as a source of lutein in tissue silks.

The results described herein demonstrate that the silk of $Z$. mays, depending on the germplasm, constitute an alternative source for obtaining lutein-rich carotenoid oleoresin, which is a compound of high commercial and industrial interest. In fact, there is also increasing interest in obtaining dietary lutein through different ways, including dietetic supplements. The food supplement FloraGLO $^{\circledR}$, prescribed for the treatment of AMD, is integrally constituted of lutein and zeaxanthin purified from marigold flowers, in which the procedures for carotenoid extraction employing this species has been patented [25]. The high recovery of carotenoids from marigold flowers has justified their usage [26]. However, the necessity of large areas for the production of marigold flowers due to its low biomass yield, approx. $140 \mathrm{~kg}$ flowers ha ${ }^{-1}$ [14], has been pointed out as a constraint to the expansion of this market. Contrarily, maize silk production does not require the increase of the maize cultivation area for obvious reasons. Furthermore, despite the lower recovery of carotenoids from maize silk compared to marigold, the usage of such a biomass is thought to be viable, because silk is considered a byproduct in the process of maize grains production, it is inexpensive and readily available at a large scale and, therefore, it is potentially attractive as a raw material for the pharmaceutical industry.

\section{Acknowledgements}

We are grateful to the Small Farmer Association (SINTRAF) for providing the landrace maize seeds.

\section{REFERENCES}

[1] M. I. Mínguez-Mosquera, D. Hornero-Méndez and A. Pérez-Gálvez, "Carotenoids and Provitamin A in Functional Foods," In: W. J. Hurst, Ed., Methods of Analysis for Functional Foods and Nutraceuticals, CRC press, Boca Raton, 2002, pp. 101-157. doi:10.1201/9781420014679.ch3

[2] S. Beatty, M. Boulton, D. Henson, H.-H. Koh and I. J. Murray, "Macular Pigment and Age Related Macular Degeneration," British Journal of Ophthalmology, Vol. 83, No. 7, 1999, pp. 867-877. doi:10.1136/bjo.83.7.867

[3] L. Brown, E. B. Rimm, J. M. Seddon, E. L. Giovannucci, L. Chasan-Taber, D. Spiegelman, W. C. Willett and S. E. Hankinson, "A Prospective Study of Carotenoid Intake 
and Risk of Cataract Extraction in US Men", The American Journal of Clinical Nutrition, Vol. 70, No. 4, 1999, pp. 517-524.

[4] P. S. Bernstein, M. D. Yoshida, N. B. Katz, R. W. Mcclane and W. Gellermann, "Resonance Raman Measurement of Macular Carotenoids in Normal Subjects and in Age-Related Macular Degeneration Patients," Ophthalmology, Vol. 109, No. 10, 2002, pp. 1780-1787. doi:10.1016/S0161-6420(02)01173-9

[5] B. P. Chew, C. M. Brown, J. S. Park and P. F. Mixter, "Dietary Lutein Inhibits Mouse Mammary Tumor Growth by Regulating Angiogenesis and Apoptosis," Anticancer Research, Vol. 23, No. 4, 2003, pp. 3333-3339.

[6] P. Bhosale and P. S. Bernstein, "Microbial Xanthophylls," Applied Microbiology and Biotechnology, Vol. 68, No. 4, 2005, pp. 445-455. doi:10.1007/s00253-005-0032-8

[7] S. Kuhnen, P. M. M. Lemos, L. H. Campestrini, J. B. Ogliari, P. F. Dias and M. Maraschin, "Antiangiogenic Properties of Carotenoids: A Potential Role of Maize as Functional Food," Journal of Functional Foods, Vol. 1, No. 2, 2009, pp. 284-290. doi:10.1016/j.jff.2009.04.001

[8] A. Alves-Rodrigues and A. Shao, "The Science behind Lutein," Toxicology Letters, Vol. 150, No. 1, 2004, pp. 57-83. doi:10.1016/j.toxlet.2003.10.031

[9] S. S. Ahmed, M. N. Lott and D. M. Marcus, "The Macular Xanthophylls," Survey of Ophthalmology, Vol. 50, No. 2, 2005, pp. 183-193. doi:10.1016/j.survophthal.2004.12.009

[10] S. P. Sundelin and S. E. Nilsson, "Lipofuscin-Formation in Retinal Pigment Epithelial Cells Is Reduced by Antioxidants," Free Radical Biology and Medicine, Vol. 31, No. 2, 2001, pp. 217-225. doi:10.1016/S0891-5849(01)00573-1

[11] B. H. Davies, "Carotenoids," In: T. W. Goodwin, Ed., Chemistry and Biochemistry of Plant Pigments, Academic Press, London, 1976, pp. 38-155.

[12] G. Ball, "Bioavailability and Analysis of Vitamins in Foods," Chapman \& Hall, London, 1998.

[13] R. Aman, R. Carle, J. Conrad, U. Beifuss and A. Schieber, "Isolation of Carotenoids from Plant Materials and Dietary Supplements by High-Speed Counter-Current Chromatography," Journal of Chromatography A, Vol. 1074, No. 1-2, 2005, pp. 99-105. doi:10.1016/j.chroma.2005.03.055

[14] M. C. Vieira, H. E. Gomes, A. Sangalli, Z. N. A. Heredia, I. R. Teixeira and M. B. M. Ramos, "Crescimento e Produção de Biomassa de Calêndula (Calendula officinalis L.) Proveniente de Dois Tipos de Diásporos e Duas Colorações de Capítulos Florais," Revista Brasileira de Plantas Medicinais, Vol. 8, No. 4, 2006, pp. 193-197.

[15] P. D. Fraser and P. M. Bramley, "The Biosynthesis and Nutritional Uses of Carotenoids," Progress in Lipid Research, Vol. 43, No. 3, 2004, pp. 228-265. doi:10.1016/j.plipres.2003.10.002

[16] Companhia Nacional de Abastecimento, “Acompan- hamento da Safra Brasileira: Grãos,” 2010. http://www.conab.gov.br

[17] Food and Agriculture Organization of the United Nations, "FAO Statistics," 2012. http://faostat.fao.org/site/339/default.aspx.

[18] J. B. Ogliari and A. C. Alves, "Manejo e Uso de Variedades Locais de Milho Como Estratégia de Conservação em Anchieta," In: W. S. Boef, M. H. Thijssen, J. B. Ogliari and B. R. Sthapit, Eds., Biodiversidade e Agricultores: Fortalecendo o Manejo Comunitário, L\&PM, Porto Alegre, 2007, pp. 226-234.

[19] A. Canci, G. A. Vogt and I. Canci, "A Diversidade Das Espécies Crioulas em Anchieta-SC: Diagnóstico, Resultado de Pesquisa e Outros Apontamentos Para a Conservação da Agrodiversidade," McLee, São Miguel do Oeste, 2004.

[20] D. V. O. Velazquez, H. S. Xavier, J. E. M. Batista and C. Castro-Chaves, "Zea mays L. Extracts Modify Glomerular Function and Potassium Urinary Excretion in Conscious Rats," Phytomedicine, Vol. 12, No. 5, 2005, pp. 363-369. doi:10.1016/j.phymed.2003.12.010

[21] S. Kuhnen, P. M. M. Lemos, L. H. Campestrini, J. B. Ogliari, P. F. Dias and M. Maraschin, "Carotenoid and Anthocyanin Contents of Grains of Brazilian Maize Landraces," Journal of the Science of Food and Agriculture, Vol. 91, No. 9, 2011, pp. 1548-1553. doi:10.1002/jsfa.4346

[22] S Kuhnen, J. B. Ogliari, P. F. Dias, M. S. Santos, A. G. Ferreira, C. C. Conham, K. V. Wood and M. Maraschin, "Metabolic Fingerprint of Brazilian Maize Landraces Silks (Stigma/Styles) Using NMR Spectroscopy and Chemometric Methods," Journal of Agricultural and Food Chemistry, Vol. 58, No. 4, 2010, pp. 2194-2200. doi:10.1021/jf9037776

[23] Z. Maksimović, D. Malenĉić and N. Kovaĉevic, "Polyphenol Contents and Antioxidant Activity of Maydis Stigma Extracts," Bioresource Technology, Vol 96, No. 8, 2005, pp. 873-877. doi:10.1016/j.biortech.2004.09.006

[24] P. M. M. Lemos, "Análise do Metaboloma Foliar Parcial de Variedades Locais de Milho (Zea mays) e Dos Efeitos Anti-Tumoral in Vitro e na Morfogênese Embrionária de Gallus domesticus," Ph.D. Thesis, Centro de Ciências Agrárias, Universidade Federal de Santa Catarina, Florianopolis, 2010.

[25] S. Swaminathan, K. Madavalappil and P. Kunhiraman, "Isolation and Purification of Carotenoids from Marigold Flowers," 2006.

http://patft.uspto.gov/netacgi/nph-Parser?Sect2=PTO1\&S ect $2=$ HITOFF $\& \mathrm{p}=1 \& \mathrm{u}=/$ netahtml/PTO/search-bool.html $\& \mathrm{r}=1 \& \mathrm{f}=\mathrm{G} \& \mathrm{l}=50 \& \mathrm{~d}=\mathrm{PALL} \& \mathrm{RefSrch}=$ yes \&Query=PN/ 7622599

[26] A. Pintea, C. Bele, S. Andrei and C. Socaciu, "HPLC Analysis of Carotenoids in Four Varieties of Calendula officinalis L. Flowers," Acta Biologica Szegediensis, Vol. 47, No. 1-4, 2003, pp. 37-40. 